\title{
Aktivitas Antimikroba Ekstrak Bakau (Rhizophora mucronata) dalam Menghambat Pertumbuhan Ralstonia Solanacearum Penyebab Penyakit Layu
}

(Antimicrobial activity of Mangrove Extract (hizophora mucronata) inhibit Ralstonia solanacearum causes of Wilt)

\author{
Saat Egra ${ }^{1 *}$, Mardhiana ${ }^{1}$, Mut Rofin ${ }^{1}$, Muhammad Adiwena ${ }^{1}$, Nur Jannah ${ }^{1}$, Harlinda Kuspradini $^{2}$, dan Tohru Mitsunaga ${ }^{3}$ \\ ${ }^{1}$ Fakultas Pertanian, Universitas Borneo Tarakan, Jl. Amal lama no. 1 Tarakan \\ ${ }^{2}$ Fakultas Kehutanan, Universitas Mulawarman, Jl. Penajam, Samarinda \\ ${ }^{3}$ The United Graduate School of Agricultural Science, Gifu University, 1-1 Yanagido, 501-1193 Gifu, Japan \\ *Email korespondensi: saat.egra.shaumi@gmail.com
}

Diterima 15 April 2019/Disetujui 10 Mei 2019

\begin{abstract}
$\underline{R}$. mucronata has been widely used as a traditional medicinal plant because it is capable of producing secondary metabolites such as tannins, alkaloids, terpenoids, sapponins and flavonoids. This study discusses the potential of leaf and stem bark as inhibitors of $\underline{R}$. solanacearum with the concentrations of 5000 ppm, 10000 ppm and 20000 ppm, positive control (Chlorampenicol), and negative control (Ethanol 40\%). The method used for the inhibitory assay uses the agar diffusion method. The results showed the moisture factor of leaves of $R$. mucronata $(0.33 \mathrm{~g})$ stem bark $(0.58 \mathrm{~g})$. The yield of leaf extract $(17.61 \%)$ stem bark (7.85\%). The percentage of inhibition showed that $\underline{R}$. mucronata leaf extract had inhibition on $R$. solanacearum at concentrations of 20000 ppm and 10,000 ppm, respectively $31 \%$ and 29\%, but on the other hand on leaves of $\underline{R}$. mucronata a concentration of 5000 ppm had no inhibitory activity. In different samples $\underline{R}$. mucronata stem bark showed an inhibition at concentrations of $5000 \mathrm{ppm}, 10000 \mathrm{ppm}$ and $20000 \mathrm{ppm}$ with a percentage value of $34 \%$, 39\%, and 44\%, respectively.
\end{abstract}

Keywords: Mangrove, Leaves, R. mucronata, R. solanacearum, Stem bark

\begin{abstract}
ABSTRAK
R. mucronata telah banyak digunakan sebagai tanaman obat-obatan tradisional karena mampu menghasilkan metabolit sekunder seperti tanin, alkaloid, terpenoid, sapponin dan flavonoid. Penelitian ini bertujuan untuk mengetahui potensi bagian tanaman daun dan kulit batang sebagai penghambat bakteri R. solanacearum, dengan konsentrasi 5000 ppm, 10000 ppm dan 20000 ppm, kontrol positif (Chlorampenicol), kontrol negatif (Etanol). Metode yang digunakan untuk uji daya hambat menggunakan metode difusi agar sumuran. Hasil penelitian menunjukan faktor kelembaban daun R. mucronata (0.33g) kulit batang (0.58g). Hasil rendemen ekstrak daun (17.61\%) kulit batang (7.85\%). Persentase penghambatan menunjukkan bahwa ekstrak daun R. mucronata memiliki daya hambat terhadap R. solanacearum pada konsentrasi 20000 ppm dan 10000 ppm masing-masing 31\% dan 29\%, namun disisi lain pada daun R. mucronata konsentrasi 5000 ppm tidak ada aktivitas daya hambat. Pada sampel yang berbeda Kulit batang $R$. mucronata menunjukkan adanya aktivitas daya hambat pada konsentrasi 5000 ppm, 10000 ppm dan 20000 ppm dengan nilai persentase secara berturut-turut 34\%, 39\%, dan 44\%.
\end{abstract}

Kata kunci: Bakau, Daun, Kulit Batang, R. mucronata, R. solanacearum.

\section{PENDAHULUAN}

Indonesia merupakan negara yang memiliki kawasan pesisir pantai sangat luas dan ditumbuhi berbagai jenis tumbuhan pantai. Salah satu tumbuhan pantai yang banyak dijumpai ialah bakau (Rhizophora). Secara umum, bakau yang masih tumbuh terdiri dari jenis-jenis vegetasi dominan yang diklasifikasikan ke dalam beberapa famili salah satunya Rhizoporaceae (Bengen 2001).

Rhizophora mucronata merupakan salah satu spesies bakau yang memiliki sifat antibakteri, antivirus dan antijamur. Antibakteri merupakan zat yang dapat menghambat atau membunuh bakteri penyebab infeksi yang masuk ke dalam jaringan kemudian berkembang biak. R.mucronata mampu menghasilkan metabolit sekunder seperti tanin, alkaloid, terpenoid, sapponin dan flavanoid (Feliatra et al.,, 2000). Senyawa flavanoid merupakan senyawa yang berpotensi sebagai senyawa antibiotik dan antibakteri dan juga merupakan bahan baku dari pestisida nabati (Purnobasuki, 2004).

Pestisida nabati merupakan pestisida yang aman terhadap lingkungan dan tidak menimbulkan resistensi terhadap hama. Bahan aktif pestisida nabati berasal dari tanaman yang mempunyai beberapa metabolit sekunder yang merupakan senyawa bioaktif seperti alkoloid, fenolik, terpenoid dan flavonoid. Pestisida nabati juga dapat 
mengendalikan penyakit layu fusarium yang disebabkan oleh bakteri Ralstonia solanacearum. Senyawa metabolit sekunder dari beberapa tumbuhan yang diduga mampu mengendalikan pertumbuhan bakteri $R$. Solanacearum, seperti pada tumbuhan mengkudu yang memilki kandungan senyawa flavonoid secara in vitro mampu menghambat pertumbuhan bakteri $R$. solanacearum (Holifah, 2006).

$R$. solanacearum merupakan penyebab penyakit layu bakteri yang dapat menginfeksi berbagai jenis tanaman terutama famili Solanaceae, seperti penyakit layu bakteri pada tanaman cabai, tanaman tomat, kentang, dan tembakau. Infeksi bakteri tersebut dapat mengakibatkan kegagalan panen serta kerugian yang besar mencapai hingga $90 \%$

\section{BAHAN DAN METODE}

\section{Alat dan Bahan}

Bahan baku $R$. mucronata diambil di Kawasan Konservasi Mangrove dan Bekantan Kota Tarakan. Bahan lain yang digunakan adalah aquades, etanol, mikroba $R$. solanacearum, nutrient agar (Difco), chloramphenicol, glukosa (Merck). Peralatan yang digunakan dalam penelitian ini yaitu spektrofotometer model Shimadzu UV Vis 1200 (Shimadzu co, Jepang), evaporator (Eyela, Tokyo), shaker, oven, autoclave model All Americans.

\section{Metode Penelitian Persiapan Sampel}

Sampel tanaman bakau (R. mucronata) diambil bagian daun dan kulit batangnya. Selanjutnya sampel dipotong agar menjadi bagian yang lebih kecil $0.5 \mathrm{~cm}$ agar mudah dalam proses pengeringan. Pengeringan sampel dilakukan di oven pada suhu $39^{\circ} \mathrm{C}$ selama 3 x 24 jam. Sampel yang telah kering kemudian dihaluskan dengan blender untuk menghasilkan serbuk kasar, kemudian perendaman dilakukan dengan etanol $96 \%$.

\section{Pengujian Aktivitas Antimikroba}

Bahan utama yang digunakan untuk pembuatan media pertumbuhan bakteri adalah nutrient agar (DIFCO). Media dicampurkan $20 \mathrm{~g}$ nutrient agar, glukosa $10 \mathrm{~g}$, dan aquades $1000 \mathrm{ml}$ dan disterilisasi dengan autoclave pada suhu $121^{\circ} \mathrm{C}$ selama 15 menit. Pengujian antimikroba dilakukan dengan menggunakan metode difusi agar sumuran. Suspensi bakteri dengan densitas setera dengan $10^{6}$ cells $/ \mathrm{ml}$ (standar 0.5 McFarland). Selanjutnya ekstrak sampel diuji dalam beberapa konsentrasi $(5000$ ppm, 10000 ppm dan 20000 ppm). Kontrol positif yang digunakan adalah Chloramphenicol dan kontrol negatif yang digunakan adalah etanol 40\%. Aktifitas antimikrobial ditandai dengan adanya zona hambat disekitar sumuran yang mengandung ekstrak, dengan angka lebih besar dari $8 \mathrm{~mm}$ dan dilakukan sebanyak 3 kali ulangan (Kuspradini, 2012).
(Nurjanani, 2011). Pengendalian $R$. solanacearum selama ini dilakukan dengan mengadakan rotasi tanaman, tumpang sari, dan menyemprot menggunakan pestisida sintetik, namun pengendalian tersebut dinilai kurang efektif (Miller dan Spoolman, 2013).

Ekstrak bakau (Rhizophora) diduga mampu menghambat pertumbuhan $R$. solanacearum karena mengandung senyawa matabolit sekunder yang bersifat antibakteri, namun sejauh ini masih sedikit penelitian yang mengungkapkan aktifitas antibakteri dari ekstrak tumbuhan bakau, sehingga perlu dilakukan penelitian untuk mengetahui potensi ekstrak tumbuhan bakau $R$. mucronata yang dapat menghambat pertumbuhan $R$. solanacaerum.

\section{HASIL DAN PEMBAHASAN}

Penelitian ini telah dilakukan pengamatan uji aktivitas antibakteri ekstrak tanaman bakau (Rhizophora mucronata) terhadap bakteri Ralstonia solanacearum. Parameter yang diamati yaitu faktor kelembaban, persentase rendemen dan persentase penghambatan

\section{Perhitungan kelembaban}

Perhitungan faktor kelembaban dilakukan setelah memperoleh nilai berat kering tanur dari sampel yang digunakan. Perhitungan ini bertujuan untuk mengetahui besarnya ketersediaan air di dalam bahan. Sampel daun segar bakau $R$. mucronata yang berat awalnya $1 \mathrm{~g}$, diperoleh berat kering tanur yaitu $0.33 \mathrm{~g}$. Sedangkan kulit batang bakau $R$. mucronata dengan berat awal yang sama diperoleh 0.58 g. Faktor kelembaban didapatkan dari pengeringan yang menggunakan suhu $100^{\circ} \mathrm{C}$. Semakin tinggi suhu suatu sampel maka sampel tersebut akan panas, sehingga mempercepat penurunan kadar air. Jumlah kadar air yang terkandung pada sampel dapat mempengaruhi ketahanan suatu sampel dalam masa penyimpanan. Daun dan kulit batang $R$. mucronata dikeringkan dengan cara dianginanginkan di udara terbuka yang terlindung dari sinar cahaya matahari. Hal ini dilakukan untuk menghindari kerusakan kandungan senyawa yang ada dalam suatu simplisia. Oleh karena itu, perhitungan ini diperlukan dalam suatu ekstrak tanaman karena penetapan kadar air memberikan batasan minimal besarnya kandungan air dalam bahan. Kadar air pada bahan harus rendah karena menurut Isnawati, Arifin (2006) kadar air yang disyaratkan untuk proses ekstraksi tidak boleh tinggi. Apabila kadar air pada ekstrak yang digunakan tinggi maka dapat memicu pertumbuhan mikroorganisme.

\section{Persentase rendemen}

Perhitungan persentase rendemen tanaman $R$. mucronata didapatkan dari bobot ekstrak sampel yang diperoleh dari proses ekstraksi. Ekstraksi daun dan kulit batang $R$. mucronata dilakukan menggunakan metode maserasi. Hasil perhitungan persentase rendemen dapat dilihat pada Tabel 1 . 
Table 1. Persentase rendemen sampel

\begin{tabular}{lccc}
\hline Sampel & Bobot Simplisia $(\mathrm{g})$ & Bobot Ekstrak $(\mathrm{g})$ & Rendemen $(\%)$ \\
\hline Daun R. mисronata & 161.68 & 22.91 & 17.61 \\
Kulit batang R. mисronata & 117.80 & 6.71 & 7.85 \\
\hline
\end{tabular}

Hasil rendemen menunjukkan bahwa jumlah ekstrak daun $R$. mucronata lebih besar (17.61\%) dibandingkan dengan kulit batang $R$. mucronata (7.85\%). Hal ini diduga semakin tinggi nilai rendemen menandakan jumlah ekstrak yang dihasilkan semakin banyak dan tingginya nilai rendemen yang dihasilkan terjadi karena bobot simplisia yang digunakan. Semakin berat bobot simplisia yang digunakan maka semakin banyak bobot ektrak dan rendemen yang dihasilkan. Perhitungan persentase rendemen bertujuan untuk mengetahui berapa jumlah simplisia yang diperlukan untuk ekstraksi agar diperoleh sejumlah ekstrak yang diinginkan. Menurut Irsyad (2013) hasil rendemen dapat dijadikan acuan untuk mengetahui jumlah simplisia yang dibutuhkan untuk pembuatan sejumlah tertentu ekstrak kental. Selain itu, penentuan rendemen juga berfungsi untuk mengetahui kadar metabolit sekunder yang terbawa oleh pelarut yang digunakan (Ukieyanna 2012).

Ekstraksi bekerja pada perusakan dinding-dinding sel sehingga akan memudahkan masuknya pelarut ke dalam sel-sel yang kemudian terjadi perpindahan masa zat aktif. Ekstraksi pelarut dilakukan dengan cara maserasi dingin. Maserasi merupakan metode ekstraksi melalui proses perendaman dan penyaringan simplisia dengan menggunakan pelarut dengan beberapa kali pengocokan atau pengadukan pada temperature suhu ruangan, sehingga zatzat yang terkandung di dalam simplisia relatif lebih aman. Pemilihan pelarut berdasarkan kelarutan dan polaritasnya agar memudahkan pemisahan bahan alam dalam sampel. Pengerjaan metode maserasi yang lama dan keadaan diam memungkinkan banyak senyawa yang akan terekstraksi (Istiqomah dan Susanty, 2013). Pemilihan pelarut etanol 96\% didasarkan pada tingkat keamanan dan kemudahan saat diuapkan serta sifatnya yang mampu melarutkan hampir semua zat, baik yang bersifat polar, semipolar, dan nonpolar serta dapat menarik senyawa flavonoid dan saponin secara optimum (Sulastri et al.,, 2015).

Semakin tinggi konsentrasi pelarut etanol yang digunakan untuk ekstraksi maka semakin besar daya merusak sel, sehingga semakin banyak senyawa yang terekstrak dan rendemen yang dihasilkan semakin tinggi (Dewi et al.,, 2014). Menurut Kayaputri et al.,, 2014, Etanol lebih mudah berpenetrasi ke membran sel untuk mengekstrak bahan dari tanaman. Etanol mempunyai polaritas yang mendekati polaritas fenol pada tanaman sehingga dapat digunakan sebagai pelarut pada ekstraksi (Saxena et al.,, 2011)
Jumlah rendemen ekstrak yang dihasilkan dipengaruhi oleh beberapa faktor, yaitu ukuran simplisia, jenis pelarut, tingkat kepolaran pelarut dan lama maserasi (Hidayati et al.,, 2018). Semakin lama waktu ekstraksi dan semakin halus ekstraknya, maka semakin banyak rendemen yang didapatkan. Semakin besar perbandingan bahan baku dan pelarut yang digunakan, maka semakin banyak ekstrak yang didapat. Untuk mendapatkan ekstrak yang lebih banyak harus dilakukan ekstraksi yang lebih lama. Penentuan rendemen berfungsi untuk mengetahui kadar metabolit sekunder yang terbawa oleh pelarut etanol, namun tidak dapat menentukan jenis senyawa terdapat pada sampel, ekstraksi dengan menggunakan bahan kering dapat menghasilkan rendemen lebih banyak dibandingkan bahan yang segar (Ukieyanna 2012).

\section{Persentase Penghambatan}

Pengamatan aktifitas antimikroba dilakukan dengan cara mengukur diameter daerah hambat di sekitar sumuran yang mengandung ekstrak. Perhitungan persentase penghambatan ditentukan berdasarkan daya hambat relatif terhadap kontrol positif. Persentase penghambatan menunjukkan bahwa ekstrak daun $R$. mucronata memiliki daya hambat terhadap $R$. solanacearum pada konsentrasi 10000 ppm dan konsentrasi 20000 ppm masing masing adalah $29 \%$ dan $31 \%$ namun, pada daun $R$. mucronata konsentrasi 5000 ppm tidak memiliki daya hambat terhadap $R$. solanacearum. Disisilain, kulit batang $R$. mucronata menunjukkan adanya aktivitas daya hambat pada konsentrasi 5000 ppm, 10000 ppm dan 20000 ppm dengan nilai persentase secara berturut-turut 34\%, 39\%, dan $44 \%$.

Pada penelitian ini digunakan sebagai kontrol positif yaitu Chloramphenicol. Chloramphenicol dikenal berspektrum luas yang efektif untuk menghambat bakteri Gram positif dan Gram negatif. Menurut Olson (2004) mekanisme dari Chloramphenicol yaitu menghambat sintesis protein, mencegah ujung amino asil t-RNA bergabung dengan peptidil transferase. Sedangkan kontrol negatif yang digunakan yaitu etanol $40 \%$ untuk mengetahui ada tidaknya pengaruh pelarut terhadap pertumbuhan $R$. solanacearu, Sehingga dapat diketahui bahwa yang mempunyai aktivitas antibakteri adalah zat uji bukan pelarut. Hasil uji aktivitas antibakteri ekstrak daun dan kulit batang $R$. mucronata terhadap $R$. solanacearum diamati setelah inkubasi 18 jam dapat dilihat pada Gambar 2. 


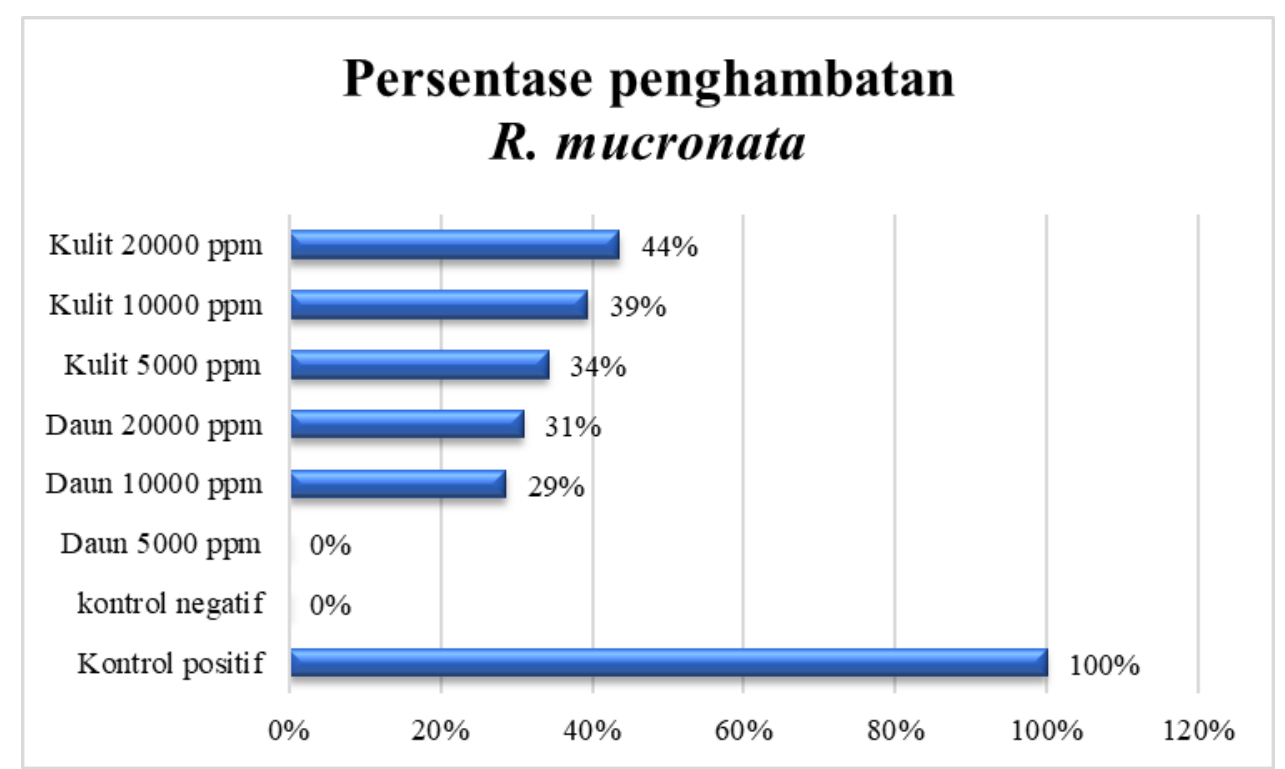

Gambar 1. Aktivitas DDH ekstrak daun dan kulit batang $R$. mucronata terhadap bakteri $R$. solanacearum.

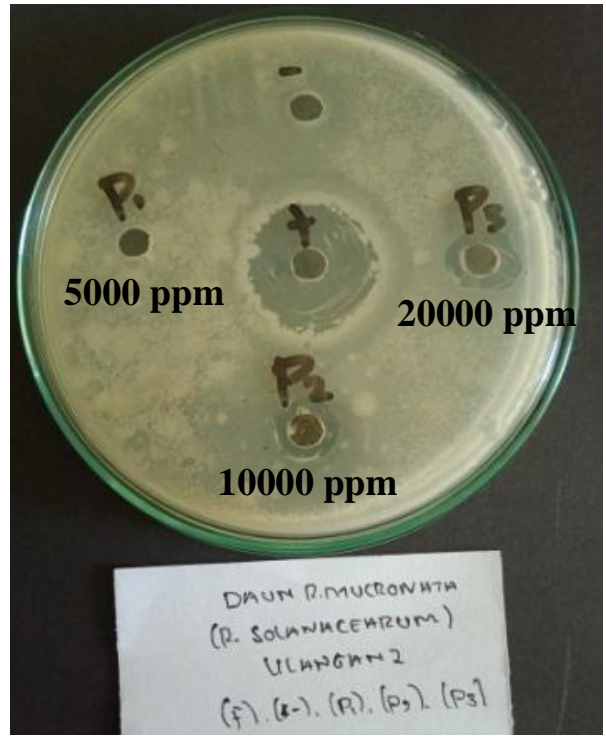

(a)

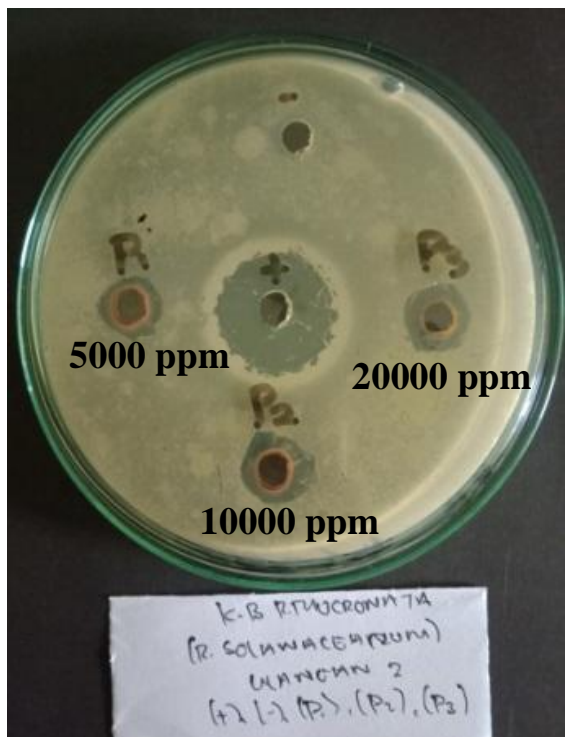

(b)

Gambar 2. DDH ekstrak daun (a) dan kulit batang (b) R. mucronata pada konsentrasi 5000 ppm, 10000 ppm, dan 2000 ppm terhadap bakteri $R$. solanacearum

Zona hambat yang terbentuk terhadap $R$. solanacearum disebabkan adanya senyawa metabolit sekunder yang memiliki aktivitas antibakteri. Penghambatan bukan berasal dari pelarut yang diperoleh pada proses maserasi. Etanol sebagai pelarut organik digunakan dalam proses maserasi untuk menarik senyawa metabolit sekunder di dalam sel tumbuhan. Pelarut organik tidak memengaruhi bioaktivitas senyawa metabolit sekunder terhadap spesies bakteri patogen (Khalil, 2012).

Beberapa faktor yang mempengaruhi aktivitas antibakteri adalah jenis bakteri yang dihambat, kandungan senyawa antibakteri, konsentrasi ekstrak dan daya difusi suatu ekstrak. Selain itu perbedaan struktur dinding sel bakteri juga menentukan aktivitas, penetrasi dan ikatan senyawa antibakteri. Bakteri $R$. solanacearum merupakan bakteri Gram negatif yang memiliki peptidoglikan tipis yakni 5-10\% (Pelczar dan Chan, 2008). Membran luar Gram negatif terdiri atas tiga lapis, yaitu lipopolisakarida (LPS), lipoprotein, dan fosfolipid, terdapat porin yang terbentuk dari protein. Porin merupakan saluran yang dapat dilalui beberapa molekul (Lamothe et al.,,, 2009). Membran luar ini berfungsi sebagai penghalang terhadap antibiotik, enzim pencernaan, dan kondisi kekeringan, namun tidak bisa menjadi penghalang terhadap semua substansi (Tortora et 
al.,, 2007). Faktor primer rusaknya dinding sel dimulai dari lipopolisakarida (LPS) dan porin. Senyawa antibakteri bekerja dengan cara menembus LPS (lipopolisakarida). Molekul-molekul yang bersifat hidrofilik akan mudah melewati LPS dibandingkan molekul hidrofobik (Tortora $e t$ al.,, 2007). Bakteri Gram negatif memiliki sisi hidrofilik yaitu karboksil, asam amino, dan hidroksil.

Mekanisme kerja antibakteri dari masing masing senyawa metabolit sekunder berbeda-beda. Senyawa metabolit sekunder menghambat pertumbuhan bakteri dimulai dengan merusak dinding sel. Senyawa flavonoid dapat menembus peptidoglikan yang bersifat polar karena flavonoid juga bersifat polar, sedangkan disisi lain senyawa fenol merusak dinding bakteri dengan memutuskan ikatan peptidoglikan (Pelczar dan Chan, 1988). Robinson (1995) juga menjelaskan bahwa mekanisme penghambatan bakteri oleh senyawa fenol diduga dengan mengganggu komponen penyusun peptidoglikan sel bakteri sehingga lapisan sel tidak terbentuk secara utuh, selain itu senyawa alkaloid bekerja dengan menghambat sintesis dinding sel (Lamothe et al.,, 2009). Ketidakstabilan pada dinding sel menyebabkan fungsi permeabilitas selektif, fungsi pengangkutan aktif, dan pengendalian susunan protein dari sel bakteri menjadi terganggu, sehingga menyebabkan sel bakteri menjadi kehilangan bentuk dan lisis (Pelczar dan Chan, 1988).

Dari hasil yang di dapatkan terjadi peningkatan zona hambat bakteri pada ekstrak yang konsentrasinya lebih tinggi, semakin tinggi konsentrasi yang diberikan maka semakin meningkat pula zona hambat bakteri. Ernawati et al.,, (2015) menyimpulkan bahwa ekstrak $R$. mucronata dengan konsentrasi yang semakin tinggi membentuk zona hambatan yang semakin besar pula dan semakin pekat konsentrasi ekstrak $R$. mucronata maka senyawa metabolit sekunder yang terdapat di dalam ekstrak tersebut semakin banyak sehingga memberi pengaruh terhadap diameter zona hambatan yang terbentuk.

Tanaman $R$. mucronata mengandung beberapa senyawa metabolit sekunder aktif yaitu flavonoid, tanin, alkaloid, dan triterpenoid. Masing-masing senyawa tersebut terbukti memiliki aktivitas farmakologi terutama sebagai antibakteri. Mekanisme kerja tanin sebagai antibakteri adalah menghambat enzim reverse transkriptase dan DNA topoisomerase sehingga sel bakteri tidak dapat terbentuk (Kordi et al 2012)

Mekanisme flavonoid dalam menghambat pertumbuhan bakteri, antara lain bahwa flavonoid menyebabkan terjadinya kerusakan permeabilitas dinding sel bakteri, mikrosom bakteri dan lisosom bakteri. Sebagai hasil interaksi antara flavonoid dengan DNA bakteri, flavonoid juga mampu melepaskan energi transduksi terhadap membran sitoplasma bakteri. Selain itu flavonoid juga dapat menghambat motilitas bakteri. Gugus hidroksil yang terdapat pada struktur senyawa flavonoid menyebabkan perubahan komponen organik dan transport nutrisi yang akhirnya akan mengakibatkan timbulnya efek toksik terhadap bakteri. (Mulyani, 2013). Menurut (Masduki 1996) Tanin memiliki aktivitas antibakteri yang berhubungan dengan kemampuannya untuk menginaktivasi adhesin sel bakteri, melalui enzim dan mengganggu transport protein pada lapisan dalam sel bakteri. Tanin juga mempunyai target pada polipeptida dinding sel bakteri sehingga pembentukan dinding sel bakteri menjadi kurang sempurna.

Alkaloid adalah senyawa metabolit sekunder terbanyak yang memiliki atom nitrogen, yang ditemukan dalam jaringan tumbuhan dan hewan. Sebagian besar senyawa alkaloid bersumber dari tumbuh-tumbuhan, terutama angiosperm. Lebih dari 20\% spesies angiosperm mengandung alkaloid (Wink, 2008). Alkaloid dapat ditemukan pada berbagai bagian tanaman, seperti bunga, biji, daun, ranting, akar dan kulit batang. Alkaloid umunya ditemukan dalam kadar yang kecil dan harus dipisahkan dari campuran senyawa yang rumit yang berasal dari jaringan tumbuhan. Selain tanin, flavonoid, dan alkoloid senyawa lain yang terkandung dalam tanaman $R$. mucronata adalah titerpenoid. Mekanisme antibakteri triterpenoid yaitu bereaksi dengan porin (protein trans membran) pada membran luar dinding sel bakteri dan membentuk ikatan polimer yang kuat sehingga mengakibatkan rusaknya porin. Rusaknya porin yang merupakan pintu keluar masuknya nutrisi sehingga senyawa penghambatan akan mengurangi permeabilitas dinding sel bakteri. Permeabilitas dinding sel bakteri ini akan mengganggu keluar masuknya nutrisi dan senyawa lainnya, sehingga pertumbuhan bakteri terhambat atau sel bakteri akan mati (Robinson 1995).

Ekstrak daun $R$. mucronata dengan konsentrasi 20000 ppm dan ektrak kulit batang dengan konsentrasi 5000 ppm merupakan konsentrasi yang efektif dalam menghambat aktifitas bakteri $R$. solanacearum. Ekstrak kulit batang $R$. mucronata mununjukkan aktivitas antibakteri yang tinggi dan bersepektrum luas, sehingga berpotensi sebagai sumber antibakteri alami. (Kordi et al., 2012).

\section{KESIMPULAN}

Persentase penghambatan menunjukkan bahwa ekstrak daun $R$. mucronata memiliki daya hambat terhadap $R$. solanacearum pada konsentrasi 10000 ppm (24.88\%) konsentrasi 20000 ppm (26.88\%) tetapi pada daun $R$. mucronata konsentrasi 5000 ppm tidak memiliki daya hambat terhadap $R$. solanacearum, pada kulit batang $R$. mucronata menunjukkan adanya aktivitas daya hambat pada konsentrasi 5000 ppm, 10000 ppm dan 20000 ppm dengan nilai persentase secara berturut-turut $(24.67 \%)$, (28.34\%) dan $(31.34 \%)$.

\section{DAFTAR PUSTAKA}

Bengen, D.G. 2000. Pengenalan dan pengelolaan ekosistem mangrove. Pedoman Teknis. PKSPL IPB. Bogor. (Indonesia).

Ernawati, H. 2015. Uji vitokimia dan antibakteri senyawa metabolit sekunder ekstrak metanol daun mangrove (Rhizopora mucronata). Jurnal biologi 3(11): 44-55. 
Feliatra. 2002. Sebaran Bakteri Escherichia coli di Perairan Muara Sungai Bantan Tengah Bengkalis Riau.Jurnal Bionature. 16 (2): 98-102

Hidayati, Novianty. 2018. Pemurnian Eugenol dari Minyak Daun Cengkeh. Jurnal Teknil Gelagar 14 (2): 108114

Holifah. 2006. Uji Potensi Antibakteri Tanaman Mengkudu terhadap Penyebab Penyakit Layu Bakteri (Ralstonia solanacearum) pada Tanaman Pisang.(Skripsi). Universitas Jember, Jember. (Indonesia)

Irsyad, M. 2013. Standardisasi Ekstrak Etanol Tanaman Katumpangan Air (Peperomia pellucida L. Kunth). UIN Syarif Hidayatullah. Jakarta.

Istiqomah, S. 2013. Perbandingan Metode Ekstraksi Maserasi Dan Sokletasi Terhadap Kadar Piperin Buah Cabe Jawa. Piperis Retrofracti Fructus. (Disertasi). UIN. Jakarta. (Indonesia).

Khalil, A. 2012. Antimicrobial Activity of Ethanol Leaf Extracts of Catharanthus Roseus from Saudi Arabia. 2nd International Conference on Environment Science and Biotechnology 48(2): 6-11.

Kordi, H. 2012. Ekosistem Mangrove Potensi, Fungsi, dan Pengelolaan. (Skripsi). Universitas Sumatera Utara, Medan. Indonesia

Kuspradini, H., D. Susanto, Ritmaleni, T. Mitsunaga. 2012. Phytochemical and comparative study of anti microbial activity of Lepisanthes amoena leaves extract. Journal of Biology, Agriculture and Healthcare 2(11): 80-86.

Lamothe, R.G., G. Mitchell, M. Gattuso, M.S. Diarra, F. Malouin, K. Bouarab. 2009. Plant Antimicrobial Agents and Their Effects on Plant and Human Pathogens. International Journal Science 10:34003419.

Masduki. 1996. Efek Antibakteri Ekstrak Biji Pinang (Areca catechu) terhadap S. aureus dan E.coli. (Disertasi). Universitas Brawijaya, Malang. (Indonesia)
Miller, G.T., S.E. Spoolman. 2013. Sustaining the Earth. 6th edition. California: Thompson Learning Inc Pacific Grove. 7 (1):144.146.

Mulyani. 2010. Flavonoid struktur, sifat antioksidatif dan peranannya 9 (2):196-202.

Nurjanani, 2011. Kajian Pengendalian Penyakit Layu Bakteri (Ralstonia Solanacearum) menggunakan Agens Hayati pada Tanaman Tomat. Jurnal Suara Perlindungan Tanaman 1(4): 1-8.

Pelczar, M.J., E.S.C. Chan. 2008. Dasar- dasar Mikrobiologi. Elements of Microbiology. Penuntun Fitokimia dalam Farmasi. 7 (2) 154-158.

Pelezar, M.J., E.C.S. Chan. 1988. Dasar-Dasar Mikrobiologi . Universitas Indonesia Press. Jakarta.

Purnobasuki, H. 2004. Potensi mangrove sebagai tumbuhan obat. (2):125-126.

Robinson, T. 1995. Kandungan Kimia Organik Tumbuhan Tingkat Tinggi. (Skripsi). Bandung Institute of Technology, Bandung. (Indonesia)

Saxena, G., Kalra. 2011. Antimicronial Activity Pattern of Certain Terpenoids. Internasional Journal of Pharma and Bio Sciences. 2(1): 87-91.

Sulastri, E., O. Cristadeolia, Yusriadi. 2015. Formulasi Mikroemulsi Ekstrak Bawang Hutan dan Uji Aktivitas Antioksidan. Jurnal Pharmascience. 2(2): 239-244.

Tortora, G.J., B.R. Funke, C.L. Case. 2007. Microbiology. 9th edition. San Francisco: Pearson Education. 7 (1): 144-150

Ukieyanna, E., Youngson. 2012. Aktivitas antioksidan, kadar fenolik, dan Flavonoid total tumbuhan suruhan. Peperomia pellucida L. (4): $2302-2493$

Wink, M. 2008. Ecological Roles of Alkaloids. (Eds.) Modern Alkaloids, Structure, Isolation Synthesis and Biology Wiley. 2(3):231-236. 